\title{
Hepatoprotective Activity of Flavonoids Purified and Ethanolic Extract from Iraqi Propolis Against Carbon tetrachloride- Induced Liver Damage In Male Mice
}

\author{
${ }^{1}$ Essam F. Al-Jumaily, ${ }^{1}$ Raghad S. Al-Obaidiand ${ }^{2}$ Jasim M.Abdulla \\ ${ }^{I}$ Biotechnology Dept. Genetic Engineering and Biotechnology Institute for post graduate studies/ Baghdad \\ University/ Baghdad/ Iraq \\ ${ }^{2}$ Biotechnology Centre, Al-Naharin University
}

\begin{abstract}
The present study aims to investigatethe antioxidant activity of flavonoids purified and methanolic extract from propolis on male mice compared to that caused by carbon tetrachloride as a hepatotoxic model by measuring the determination of catalase, glutathione peroxidase and superoxide dismutase change in liver damage.

The results showed that the enzymes antioxidants (Glutothinone peroxidase (GPx) and Superoxide dismutase $(S O D)$ had increased significantly $(P<0.015)$ after it has been feeding male mice carbon tetrachloride, and that each of the flavonoids purified at a concentration (500 and $1000 \mathrm{mg} / \mathrm{kg}$ ) and ethanolic extract at a concentration (500 $\mathrm{mg} / \mathrm{kg}$ ) has led to decreased Glutothinone peroxidase enzyme (GPx) activity significantly $(P<0.05)$ compared to the control treatment after feeding them for 14 days. The ethanolic extract for propolis concentration of $1000 \mathrm{mg} / \mathrm{kg}$ and vitamin C concentration of $180 \mathrm{mg} / \mathrm{kg}$ has led to increased significantly $(P<0.05)$ when compared with the treatment of control but a level significantly lower $(P<0.05)$ compared with the treatment tetrachloride carbon.Either Superoxide dismutase (SOD) has led flavonoids pure and ethanolic extract for propolis ( $500 \mathrm{and} 1000 \mathrm{mg} / \mathrm{kg}$ ) to increase significantly the level $(P<0.05)$ compared to treatment tetrachloride carbon, and vitamin $C$ which led to a decline in the level of the enzyme significantly $(P<0.05)$ when feeding them for 14 days. Either enzyme catalase $(C A T)$ has led flavonoids pure and ethanol extract of propolis ( 500 and $1000 \mathrm{mg} / \mathrm{kg}$ ) to decrease significantly $(P<0.05)$ compared to treatment tetrachloride carbon and control group as well as when feeding with vitamin $C$ and ethanol extract alone at a concentration $(1000 \mathrm{mg} / \mathrm{kg})$ led to a significant decrease of the level $(P<0.05)$. The study concluded that flavonoids pure and ethanolic extract of Iraqi propolis has led to a reduction of the inhibitory effect as well as for damage to the work of the liver and there by protect members from free radicals and inhibit the liberation of these ROS.
\end{abstract}

Key Words: enzymes antioxidant (Glutothinone peroxidase, Superoxide dismutase, catalase), Iraqi Propolis, flavonoids purified, methanolic extract.

\section{INTRODUCTION}

Propolis (bee glue) is the generic name for the resinous substance collected by honey bees (Apismellifera) from various plant sources and used by bees to seal holes in their honeycombs, smooth out the internal walls, and protect the entrance against intruders [1]. It is rich in biochemical constituents, and more than 300 compounds have been identified; including a mixture of polyphenols, flavonoids, phenolic acid and their esters, phenolic aldehydes and ketones, terpenes, sterols, vitamins, amino acids, and others ,among which phenolics predominate [2]. Healing properties of propolis are known in folk medicine from antiquity; however, recently, the interest in propolis as harmless medicine is increasing. There have been many attempts to validate biological effects of propolis and elucidate its composition [3]. Anti-oxidant and immunomodulatory potentials of propolis have also been recorded[4,5].Many studied in human beings and rats have been conducted to clarify the relationship between oxidative stress and antioxidants in the liver. In human beings, when suffering from free oxygen radicals, a complex defense system is activated. This system includes GPx, SOD, CAT, glutathione, glutathione reductase and vitamins.

The present study aims to determined the antioxidant activity of flavonoid purified and ethanolic propolis extract on male mice compared to that caused by carbon tetrachloride as a hepatotoxic model by measuring the determination of catalase, glutathione peroxidase and superoxide dismutase change in liver. 


\section{Preparation of Propolis Extraction:}

\section{II.MATERIALS and METHODS}

The Iraqi propolis raw samples were collected from local Iraqi market, by scraping the sample off from the frames of beehives. The locations of hives in Baghdad. The samples of propolis were kept in the dark and stored in room temperature, at which the extraction, chemical analysis and the other laboratory investigations were carried out. The ethanol extract propolis (EEP) was prepared according to a method presented byNikolovet al.1987 [8] with modifications. Flavonoid purified extract was obtained by gel filtration Colum(Sephadx LH-20) according to Al-Jumaily and Al-Obaida,2013[9].

\section{Experimental design:}

Thirty-two Male albino mice (25-28 gm) of about six weeks old have been obtained from the Institute of Embryo Researches and Infertility Treatment / Al-Nahrain University and bred in the animal house of Biotechnology Researches Center / Al-Nahrain University were used in this study. They were randomly selected and kept in eighty groups of 4 mice per group. Each group was kept in a separate cage. All animals were fed with commercially formulated mice feed and tap water ad libitum that supplied by the center. Their cages were cleaned daily; food and water have been changed daily. The animals were allowed to acclimatize for 2 weeks.

\section{Treatment schedule of animals :}

Thirty- two mice have been used to study the possible antioxidant effect of different doses of

flavonoid purified propolis and ethanol extract propolis compared to $\mathrm{CCl}_{4}$-induced liver damage allocated as follows: Group A- four mice were received regular standard diet, tap water for 14 days and severed as control (A). Male mice in the $2^{\text {nd }}$ group (B) were received carbon tetrachloride $(3.2 \mathrm{mg} / \mathrm{kg}$ ). The first day and the eighth and severed as positive control. Mice in the $3^{\text {rd }}$ group $(\mathrm{C})$ were received oral daily dose of flavonoid purified propolis $500 \mathrm{mg} / \mathrm{kg} /$ day, for 14 day and treated with $\mathrm{CCl}_{4}$ first and eight day. Mice in the $4^{\text {th }}$ group (D) were received oral daily dose of flavonoid purified propolis $1000 \mathrm{mg} / \mathrm{kg} /$ day, for 14 day and treated with $\mathrm{CCl}_{4}$ first and eight day. Mice in $5^{\text {th }}$ group (E) were received oral daily dose of ethanol extract propolis $500 \mathrm{mg} / \mathrm{kg} / \mathrm{day} \mathrm{for}$ 14 day and treated with $\mathrm{CCl}_{4}$ first and eight day. Mice in $6^{\text {th }}$ group $(\mathrm{F})$ were received oral daily dose of ethanol extract propolis $1000 \mathrm{mg} / \mathrm{kg} /$ day for 14 day and treated with $\mathrm{CCl}_{4}$ first and eight day. Mice in $7^{\text {th }}$ group $(\mathrm{G})$ were received oral daily dose of ethanol extract propolis $1000 \mathrm{mg} / \mathrm{kg} /$ day for 14 day. While mice in the group $(\mathrm{H})$ were received oral daily dose with vitamin C $180 \mathrm{mg} / \mathrm{kg} /$ day for 14 day and treated with $\mathrm{CCl}_{4}$ first and eight day. Animals in all groups were killed by anesthetic ether on the day 15.

The experimental protocol was approved by the institutional animal ethics committee of NRI Medical College and General Hospitalin accordance with CPCSEA (Committee for The purpose and control and supervision on Experiments on Animals guidelines).

\section{Tissue homogenate}

prior to dissection either perfused or rinse tissue with a PBS(phosphate buffer saline) solution, $\mathrm{pH} 7.4$, to remove any red blood cells and clots homogenize the tissue in 5-10 ml of cold buffer (50 mM MES or phosphate, $\mathrm{pH} 6-7$, containing $1 \mathrm{mM}$ EDTA) per gram tissue centrifuge at $10,000 \mathrm{xg}$ for $15 \mathrm{minutes}$ at $4^{\circ} \mathrm{C}$ remove the supernatant and store on ice the supernatant will have to be deporteinated before assaying, if not asssying in the same day the sample will still have to be deporteinated and then stored at $-20 \mathrm{C}^{\mathrm{o}}$ the sample will be stable for at least six months.

\section{Biochemical assay: \\ SOD determination in Tissuse. (Crapo et al.,1978)[10]}

One unite of SOD was defined as the 50\% inhibition activity of SOD can be determined by calorimetric method, absorbance can be measured 440nm.Calculation:

$\%$ inhibition = A control - A sample/ A control x100

\section{Determination of glutathione peroxidase $\mathbf{G p}_{\mathbf{X}}$ (Floh and Gunzler,1984)[11]}

The $\mathrm{GP}_{\mathrm{X}}$ enzyme catalyzes the reduction of $\mathrm{H}_{2} \mathrm{O}_{2}$ to water and organic peroxides $(\mathrm{R}-\mathrm{O}$ -

$\mathrm{OH})$ to the corresponding stable alcohols using glutathione as a source of reducing equivalents. One unite will catalyze the oxidation by $\mathrm{H}_{2} \mathrm{O}_{2}$ of 1.0 Mole of reduced glutathione to oxidized glutathione per minute at $\mathrm{pH} 7.0$ at $25^{\circ} \mathrm{C}$. 


\section{Determination of Catalase : (Racker, 1955)[12]}

Catalase enzyme was defined as the one unit is the amount of enzyme that catalyses' the reaction of 1 mmol of substrate per minute the activity (units/ml) of your diluted enzyme sample is given by the following equation:

Enzyme activity $($ micromoles $/ \mathrm{min} / \mathrm{ml})=\left(\mathrm{A}^{*} \mathrm{D}\right) / \mathrm{E}$

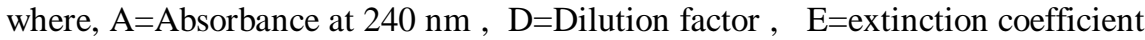

\section{Statistic alanalysis:}

Completely randomized design (CRC) program (SAS,2001)[13].was used to test the effect of the treatment on traits involved in this study. The least significant difference (LSD) test was also used to compare significance between the means (Steel and Torrie, 1980)[14].

\section{RESULTS AND DISCUSSION}

Figure (1) shows a significant $(\mathrm{p}<0.05)$ decrease in the liver activity level of GPx in mice treated with $1000 \mathrm{mg} / \mathrm{kg}$ of flavonoid purified propolis for 14 days (group D) as compared to the level in mice treated with $500 \mathrm{mg} / \mathrm{kg}$ (group C) which reach $(0.06$ and 0.084 unit/L respectively) compared to control mice $\operatorname{group}(\mathrm{A})(0.086$ unit/L). Also there was a significant $(\mathrm{p}<0.05)$ decrease in the liver activity level of GPx in mice treated with $1000 \mathrm{mg} / \mathrm{kg}$ of ethanol extract propolis (group F) to 0.064 (unit/L) for 14 days as compared to the level in mice treated with $500 \mathrm{mg} / \mathrm{kg}$ dose of the ethanol extract propolis (group E ) to 0.081 unit/L (but still significantly $(\mathrm{p}<0.05)$ less than control treated group.

Mice treated with $1000 \mathrm{mg} / \mathrm{kg}$ of ethanol extract propolis only showed a significant $(\mathrm{p}<0.05)$ increase in the liver activity level of GPx to $(0.139$ unit/L) (group G) as compared to control group, but significantly $(\mathrm{p}<0.05)$ less than $\mathrm{CCl} 4$-treated group B $(0.19$ unit/L).(Figure 1$)$

Mice treated with $180 \mathrm{mg} / \mathrm{kg}$ of essential vitamin $\mathrm{C}$ a significant $(\mathrm{p}<0.05)$ decrease in the liver activity level of GPx to $(0.138$ unit/L) (group H) as compared to control group, but significantly $(\mathrm{p}<0.05)$ less than CCl4-treated group (Figure 1). In contrast, flavonoid and ethanol extract propolis were able to modulate these effects, and showed their ability in reducing the level of liver function enzymes. Furthermore, propolis was found and decrease lipid peroxidation process in plasma ,liver ,lungs and brain of mice in dose and tissue depended manner [15].GPx is a selenocysteine-dependent enzyme that protects against oxidative injury. Endogenous activity of GPx is dependent on an adequate supply of the micronutrient selenium[16].GPx enzymes are the most important hydrogen peroxide $\left(\mathrm{H}_{2} \mathrm{O}_{2}\right)$-removing enzymes in mammalian cells[17]. Okutanet al., (2005)[18]were agreement with present result that GPx activity of blood ,liver and kidney in the control group were significantly reduced while SOD and GSH activities were increase in blood and some tissue.

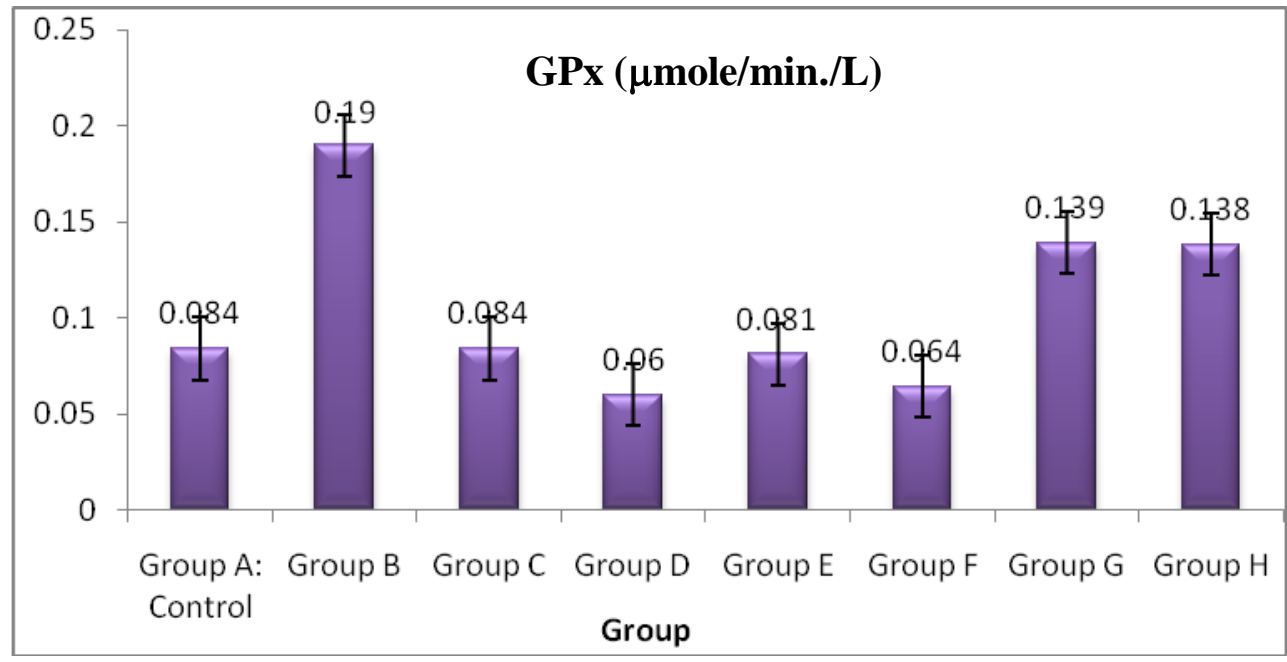

Figure 1: Effect of different dose of flavonoid purified and ethanol extract propolis on the activity of glutathione peroxidase (GPx). 
Figure (2) showed that the $\mathrm{CCl} 4$ treated mice increase a significant $(\mathrm{p}<0.05)$ in the liver activity level of SOD (18.81 unit/ml) (group B) compared to control group (11.18 unit/ml) (group A).Mice treated with 500 and $1000 \mathrm{mg} / \mathrm{kg}$ of flavonoid purified propolis (group C and D respectively) showed a significant ( $<0.05$ ) increase in the level of SOD (17.95 and $14.25 \mathrm{unit} / \mathrm{ml}$ respectively) as compared to the control group but significantly $(\mathrm{p}<0.05)$ less than carbon tetrachloride - treated mice. Also, mice treated with 500 and $1000 \mathrm{mg} /$ $\mathrm{kg}$ of ethanol extract propolis ( group $\mathrm{E}$ and $\mathrm{F}$ respectively) showed a significant $(\mathrm{p}<0.05)$ increase in the level of SOD( 22.42 and $15.68 \mathrm{unit} / \mathrm{ml}$ respectively) as compared to the control group.

Mice treated with $1000 \mathrm{mg} / \mathrm{kg}$ of ethanol extract propolis only (group G) showed a significant $(\mathrm{p}<0.05)$ decrease in the level of SOD $(10.5 \mathrm{unit} / \mathrm{ml})$ as compared to the control group but significantly $(\mathrm{p}<0.05)$ less than carbon tetrachloride - treated mice.(Figure 2).

Mice treated with $180 \mathrm{mg} / \mathrm{kg}$ of vitamin $\mathrm{C}$ (group H) showed a significant $(\mathrm{p}<0.05)$ decrease in the level of SOD (9.1) as compared to the control group and also significantly $(\mathrm{p}<0.05)$ less than carbon tetrachloride - treated.

In the present study showed a significant increase in hepatic tissue SOD, activities in mice with CCl4treated compared with control group Figure(2). The SOD is a group of metalloenzymes whose function appeared to be protection of cells from the toxic effects of the endogenously generated superoxide radicals [19]. Szymonik-Lesiuk et al (2003) [20] reported that in the kidney of rats exposed to CCl4,CCl4 would reduce SOD and CAT activities and that oxidative stress in the liver was induce by CCl4 in oxidant cause a decrease in SOD and GPx activities or that reactive intermediary product occurred during the bio-activation of $\mathrm{CCl} 4$ could inactive SOD and GPx enzymes.

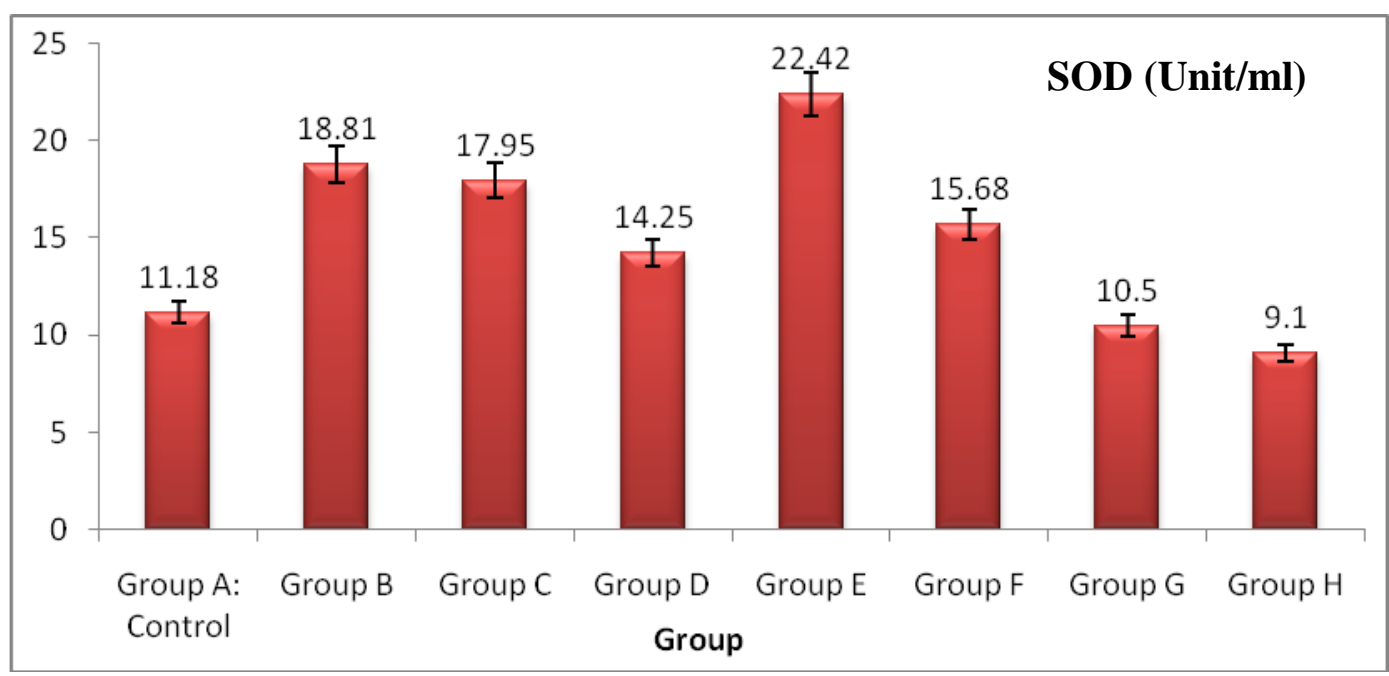

Figure 2: Effect of different dose of flavonoid purified and ethanol extract propolis on the activity of SOD

$\mathrm{CCl} 4$ treated mice showed a significant $(\mathrm{p}<0.05)$ decrease the liver tissue activity level of catalase (CAT) $(0.101 \mu \mathrm{mole} / \mathrm{min} . / \mathrm{ml})$ (group B) compared to control (group A) $(0.172 \mathrm{unit} / \mathrm{ml})$. Figure (3).

From Figure (3) also, showed that mice treated with 500 and $1000 \mathrm{mg} / \mathrm{kg}$ of flavonoid purified propolis showed a significant $(\mathrm{p}<0.05)$ decrease in the level of CAT $(0.048$ and $0.054 \mathrm{unit} / \mathrm{ml}$ respectively) as compared to the control group but significantly $(\mathrm{p}<0.05)$ less than carbon tetrachloride - treated mice ( group B). Mice treated with 500 and $1000 \mathrm{mg} / \mathrm{kg}$ of ethanol extract propolis showed a significant $(\mathrm{p}<0.05)$ decrease in the level of CAT ( 0.088 and $0.056 \mathrm{unit} / \mathrm{ml}$ respectively) as compared to the control group but significantly $(\mathrm{p}<0.05)$ less than carbon tetrachloride - treated mice.

But when the mice treated with $1000 \mathrm{mg} / \mathrm{kg}$ of ethanol extract propolis only showed a significant $(\mathrm{p}<0.05)$ decrease in the level of CAT $(0.044 \mathrm{unit} / \mathrm{ml})$ (group G) as compared to the control group but significantly $(\mathrm{p}<0.05)$ less than carbon tetrachloride - treated mice. When the mice treated with $180 \mathrm{mg} / \mathrm{kg}$ of vitamin $\mathrm{C}$ showed a significant $(\mathrm{p}<0.05)$ decrease in the level of CAT $(0.052 \mathrm{unit} / \mathrm{ml})($ group H $)$ as compared to the control group but significantly $(\mathrm{p}<0.05)$ less than carbon tetrachloride - treated mice.

Catalase is an essential enzyme in the decomposition of intracellular $\mathrm{H}_{2} \mathrm{O}_{2}$. It promotes the breakdown of $\mathrm{H}_{2} \mathrm{O}_{2}$ into water and oxygen without producing free radicals. Catalase, which is located in peroxisomes, is found in essentially all aerobic cells [16]. 


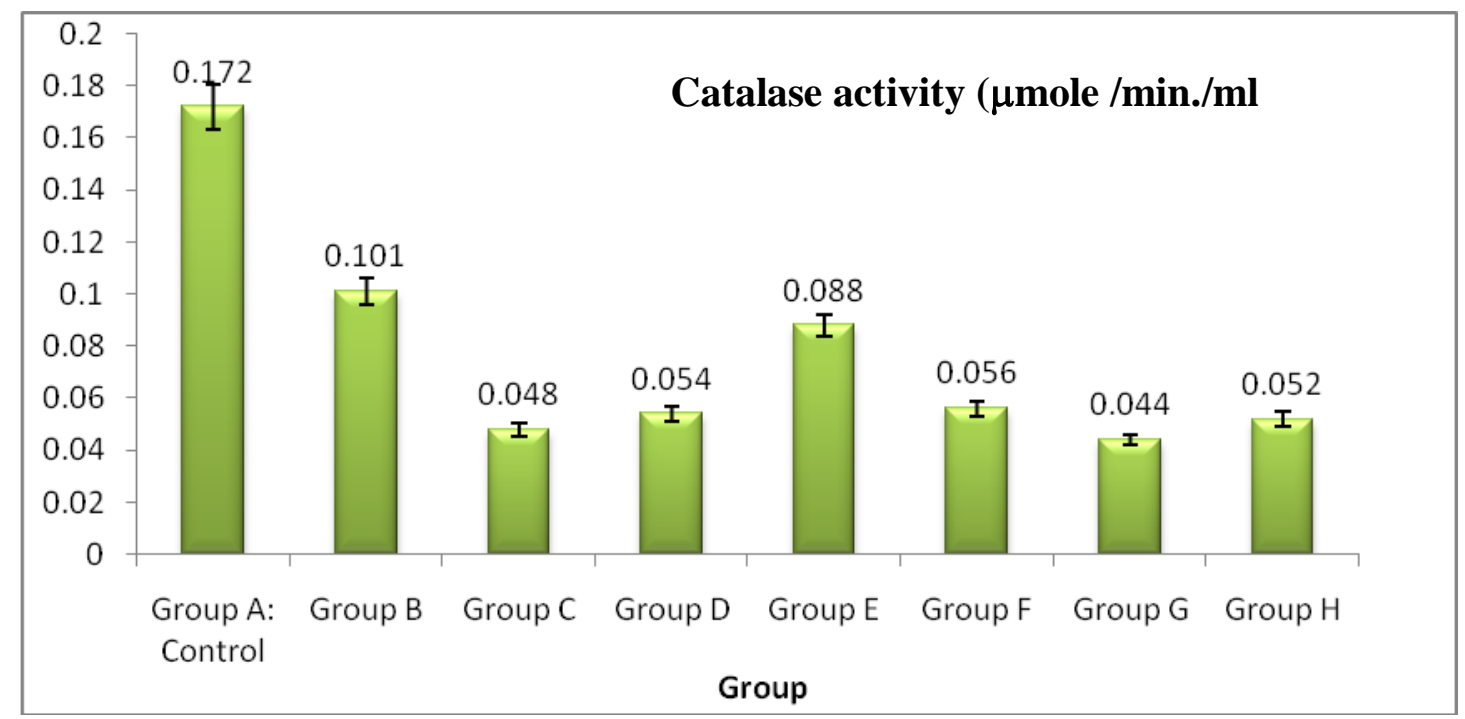

Figure 3: Effect of different dose of flavonoid purified and ethanol extract proplois on the liver tissue activity level of Catalase (CAT)

In the current study the significant decrease in the antioxidant enzyme activities (SOD, GPx and CAT) in liver tissue suggested that $\mathrm{CCl} 4$ induced oxidative stress this results agreement with Atessanin et al.,(2005)[21] who reported that administration of propolis has been shown to produce oxidative stress by generating reaction oxygen species and reducing the antioxidant.

Carbon tetrachloride (CCl4) is wall-known hepatoxic and its exposure induces hepatorenal injury via oxidative stress and biochemical alteration.Oxidative stress is a major pathogenetic event occurring in several liver disorders ranging from metabolic to proliferate ones, and is a major cause of liver damage in ischemia/reperfusion during liver transplantation [22].

CAT, GPx and SOD play a vital role in protecting cellular damage from the harmful effect ROS (reactive oxygen species), the stimulation in lipid peroxidation decrease with addition of some antioxidant matter [23].

The antioxidant enzymes serves as a defensive factor against free radicals in body such as SOD,CAT and GPx are the main system that opposes oxidative if production free radical overwhelm the capacity of enzymatic system the second line of defense vitamin may to action [24] .

Antioxidant enzyme activity such as SOD,CAT and GPx may sometime decrease [25] or increase [26].When the antioxidant enzyme activity increase such as SOD,CAT and GPx may be consider as a protective mechanism against CCl4-induce free radical production [27] improvement of SOD activity in mice by propolistreatment was demonstrate [28].

McArdle and Jackson (2000)[29] have also demonstrate a significant increase in free radical production tighter with an increase in the expression of antioxidant enzyme activities during a period of non-damaging exercise these increase in antioxidant activities have been consider as protective response against oxidative stress.

\section{CONCULSION}

Iraqi propolis are rich in chemical constituents that have important biological potential for instance antioxidant. Propolis and methanol extract when use of high doses $(500$ and $1000 \mathrm{mg} / \mathrm{kg})$ even for short period of time could be toxic to liver.

\section{ACKNOWLEDGEMENT}

Authors are thankful to the council of the Institute of Genetic Engineering and Biotechnology for Postgraduate Studies, Baghdad University, for providing laboratory facilities. 


\section{REFERENCES}

[1]. Benkovic ,V. H.; Knezevic, A. H.; Brozovic, G.; Knezevic, F.; Dikic, D.;Bevanda, M.; Basic, I. and Orsolic, N.(2007). Enhanced antitumor activity of irinotecan combined with propolis and its polyphenolic compounds on Ehrlich ascites tumor in mice. Biomed.Pharmacother., 61: 292-297.

[2]. Kumar, N.; Mueen, A. K. K.; Dang, R.; Shivananda, T. N. and Das, K. (2009). GC-MS analysis of propolis of Indian origin.Pharmacognosy, 1: 46-48.

[3]. Castaldo, S.andCapasso, F. (2002). Propolis, an old remedy used in modern medicine. Fitoterapia, 73 : S1 -S6.

[4]. Naik, D. G.; Vaidya, H. S. and Behera, B. C. (2009). Antioxidant properties of Indian propolis. J. Api. Pro.Api Med. Sci., 1: 110120.

[5]. Syamsudin, Dewi, R. M. and Kusmardi, (2009). Immunomodulatory and in vivo antiplasmodial activities of propolis extracts. Am. J. Pharmacol. Toxicol., 4: 75-79.

[6]. Ercin CN, Bagci S, Yesilova Z, Aydin A, Sayal A, Erdem G (2008). Oxidative stress in extrahepatic cholestasis. Anatol J Clin Investig.;2:150-4.

[7]. Al-Bahrani, M.H.A. (2008). The role of extracellular oxygen radicals of Enterococcus faecalis in causing colonic cancer. M.Sc. thesis .IGEB , Baghdad University. Iraq.

[8]. Nikolov, N.; Marekov, N.; Bankova, V.; Popov, S.; Ignatova, R. and ladimirova,I. (1987). Method for the preparation of watersoluble derivative of propolis.Bulgarian Patent Application N 79903/28.05.

[9]. Al-Jumaily, E.F. and Al-Obaida, R.S. (2013).Extraction and purification of flavonoid From Iraqi propolis (Bee Glue) and evaluate its antioxidant activity.Online International Interdisciplinary Research J., 3(6): Pp: 3-13.

[10]. Crapo, J. D., McCord, J. M. and Fridovich, I. (1978) Methods Enzymol.,53, 382.

[11]. Flohe, L., and Gunzler (1984). W.W., Methods in Enzymol., 105, 114 -121.

[12]. Racker, E. (1955). Method in Enzymology. Martindale: The Extra pharmacopeia 28th edn., The pharmaceutical press, London. PP. 691-692.

[13]. SAS,(2001).SAS/STAT User. Guide for personal computers.Release6.12.SASInstitute Inc.,Cary,Nc.,USA.(SAS= Statistical analysis system).

[14]. Steel,R.G.D.a n d Torrie,J.H.(1980)Principle and Procedures of Statistics,McGraw-H.11. Book CompanyInc.

[15]. Shinohara R., OhtaY., Hayashi T., and IkenoT(2002) .Evaluation of antilipid peroxidative action of propolis ethanol extract. Phytother Res. 16:340-347.

[16]. Skoneczny, Marek and RYTKA, (2000) Joanna. Oxygen and haem regulate the synthesis of peroxisomal proteins: catalase A, acylCoA oxidase and Pex1p in the yeast Saccharomyces cerevisiae; the regulation of these proteins by oxygen is not mediated by haem. Biochemistry Journal, August, vol. 350, no. 1, p. 313-319.

[17]. Halliwell, B. (1994). Free radicals and antioxidants, and human disease curiosity, cause, or .

[18]. OkutanH, Ozcelik N, Yilmaz HR, UzE( 2005): Effects of caffeic acid phenethyl ester on lipid peroxidation and antioxidant enzymes in diabetic rat heart. ClinBiochem38: 191-196.

[19]. ChrobotAM, Szaflarska-Szczepanik A, Drewa G, 2000, Antioxidant defense in children with chronic viral hepatitis B and C, Med SciMonit, 6, 713-8.

[20]. Szymonic-Lesiuk S, Chechowska G, Stryjecka M, (2003) . Catalase, superoxide dismutase, and glutathione peroxidase activities in various rat after carbon tetrachloride intoxication. J Hepatobiliary Pancreat Surg;10:309-15.

[21]. Atessahin, A.; Yilmaz, S.; Karahan, I.and Tasmedir, P. B. (2005) :"The effects of vitamin E and selenium on cypermethrin induced oxidative stress in rats". Turk. J.Vet. Anim. Sci., 29: 385-91.

[22]. Cesaratto L, Vascotto C, Calligaris S, Tell G. (2004). The importance of redox state in liver damage. Ann Hepatol 3: 86-92.

[23]. Seven, I.; Aksu, T. and Tatli Seven, P. (2010). The effects of propolis on biochemical parameters and activity of antioxidant enzymes in broilers exposed to lead-induced oxidative stress. AJAS,23, 1482-1489.

[24]. Tatli Seven, P.; Yılmaz, S.; Seven, İ.; lerçi, İ.H.; Azman, M.A. \&Yılmaz, M. (2009) The effect of propolis on selected blood indicators and antioxidant enzyme activities in broilers under heat stress. Acta Vet Brno, 78, 75-83.

[25]. Ozkaya YG, Agar A, Yargicoglu P, Hacioglu G, B1lmen-Sarikcioglu S, Ozen I, Alıciguzel Y( 2002): The effect of exercise on brain antioxidant status of diabetic rats. Diabetes Metab28: 377-384.

[26]. Aliciguzel Y, Ozen I, Aslan M, Karayalcin U (2003). Activities of xanthine oxidoreductase and antioxidant enzymes in different tissues of diabetic rats. J Lab Clin Med 142: 172-177.

[27]. Altan O, Pabuccuoglu, A; Altan ,A; Konyalioglu, S and Bayraktar ,H (2003). Effect of heat stress on oxidative stress, lipid peroxidation and some stress parameters in broilers. Br PoultSci 44: 545-550.

[28]. Luan J., Wang N., and Tian L.,(2000). Study on the pharmacologic effect of propolis. Zhong Yao Cai;23(6):346-348.

[29]. McArdle A, and Jackson M.J.( 2000): Exercise, oxidative stress and ageing. J Anat 197: 539-541. 